\title{
Activated Bentonite: Low Cost Adsorbent to Reduce Phosphor in Waste Palm Oil
}

\author{
Muhammad Naswir ${ }^{1}$, Susila Arita ${ }^{2}$, Widi Hartati ${ }^{2}$, Lusi Septiarini ${ }^{2}$, Desfaournatalia ${ }^{2}$, Yudha Gusti Wibowo ${ }^{3}$ \\ ${ }^{1}$ Department of Engineering, Universitas Jambi, Jambi, Indonesia \\ ${ }^{2}$ Lecturer, Department of Chemical Engineering Universitas Sriwijaya, Indonesia \\ ${ }^{3}$ Postgraduate Student and Research Assistant, Universitas Jambi, Indonesia \\ Correspondence: Muhammad Naswir, Department of Engineering, Universitas Jambi, Jambi, Indonesia. \\ E-mail: m.naswir@yahoo.com
}

Received: April 7, 2019

doi:10.5539/ijc.v11n2p67
Accepted: June 20, 2019 Online Published: July 18, 2019

URL: https://doi.org/10.5539/ijc.v11n2p67

\begin{abstract}
The Palm Oil Factory produces wastewater containing high enough Phosphor (P). High levels of Phosphor can cause pollution load for the environment, so it needs to be lowered. The decrease of this content can be done by adsorption process using bentonite as adsorbent. The purpose of this research is to determine the absorption of activated bentonite to the absorption of Phosphor contained in waste water. Phosphor measurements were performed using the UV-vis Spectrophotometric Instrument. Bentonite was activated using $\mathrm{HCl} \mathrm{1.6} \mathrm{M.} \mathrm{Characterization} \mathrm{of} \mathrm{bentonite} \mathrm{using} \mathrm{X-ray}$ diffraction (XRD) and Scanning Electron Microscopy with Energy Divertive Spectroscopy (SEM-EDS). The results showed that bentonite was able to adsorb Phosphor contained in the waste water of Palm Oil Factory, with adsorption capacity $>90 \%$. Activated Bentonite has greater power capability than natural bentonite.
\end{abstract}

Keywords: waste water of palm oil factory, phosphor, bentonite, activation, adsorption

\section{Introduction}

Industrial waste is problem in the world including solid, liquid and gas (Winarno et al., 2019). Wastewater is a part of liquid industrial waste and gives some negative impact for human end environment (Wibowo \& Sadikin, 2019). Curt Palm Oil industry is a part of industrial activities that produce wastewater. Wastewater has a low pH, high heavy metal contents, organic matter, temperature and else such as Fe, Pb. Mg, Al, Mn, P and else (Naswir \& Lestari, 2014). Wastewater content will give some negative impact such as disease skin, poisoning, cancer and dead (Wibowo et al., 2019). Pam oil factory has been producing liquid waste, the liquid waste of palm oil processing plants contains high organic materials such as Nitrogen $(\mathrm{N})$, Phosphorous $(\mathrm{P})$, and Potassium $(\mathrm{K})$. Organic materials are nutrients so that liquid waste is likely to be used as a source of nutrients for plants. However, if the N, P, and K content of the palm oil mill's waste water exceeds the threshold it can pollute the environment and disrupt the aquatic plant and animal ecosystems (Chavalparit et al., 2006). Phosphorus (as phosphate, $\mathrm{PO}_{4}{ }^{3-}$ ) is an integral component of important compounds of plant cells, including the sugar-phosphate intermediates of respiration and photosynthesis, and the phospholipids that make up plant membranes. It is also a component of nucleotides used in plant energy metabolism (such as ATP) and in DNA and RNA(Taiz \& Zeiger, 2002). Thus, the phosphor is a limiting factor in the composition of the aquatic phytoplankton as a manufacturer.

Recent study informs about raw material to reduce parameters in wastewater include waste palm oil (Naswir, 2016). Bentonite is a raw material could reduce parameters of wastewater, bentonite is a potential low-cost adsorbent to reduce phosphorous in waste palm oil (Naswir et al., 2014). Indonesia has many bentonites deposited spread throughout Indonesia (Yuliyanti et al., 2011). Bentonite can reduce phosphorous in waste palm oil using adsorption system. Adsorption can be used to reduce the P content of palm oil mill waste (Naswir, Arita, \& Sani, 2011). Adsorption is the absorption of a substance (molecule or ion) on the surface of the adsorbent. Zeolite as an adsorbent gets more attention for applications in environmental protection and sustainability. Bentonite has superior properties to adsorb because the size of colloidal particles is very small and has a high ion surface capacity. Several studies on the use of bentonite have been applied to the absorption of inorganic elements such as $\mathrm{Cd}^{2+}, \mathrm{Pb}^{2+}, \mathrm{Cu}^{2+}, \mathrm{Mn}^{2+}, \mathrm{NO}_{3}^{-}, \mathrm{Ni}$, and Fe. The use of bentonite applied to the absorption of organic compounds has also been carried out (Naswir et al., 2013). In this research, bentonite is suggested as an alternative material, because the potential of clay reserves in Indonesia is very 
large and spread almost in all areas one of them is Jambi Province. However, its utilization has not been optimal yet.

Thus, this paper will describe clearly of utilization of bentonite to reduce phosphorous in waste palm oil, this research will give some positive impact to industrial activities to reduce environmental management cost.

\section{Research Methodology}

\subsection{Tools and Materials Research}

This research use Scanning Electron Microscopy with Energy Dispersive Spectroscopy (SEM-EDS), X-Ray Diffraction (XRD), UV-Vis spectrophotometry, and atomic absorption spectrophotometer (AAS) for characterization. The materials used in this study are Sample wastewater in aerobic and anaerobic ponds, bentonite, $\mathrm{HCl}$, $\mathrm{PP}$ indicator, $\mathrm{H}_{2} \mathrm{SO}_{4}$, ethanol, $\mathrm{K}(\mathrm{SbO}) \mathrm{C}_{4} \mathrm{H}_{4} \mathrm{O}_{6} .1 / 2 \mathrm{H}_{2} \mathrm{O},\left(\mathrm{NH}_{4}\right) 6 \mathrm{Mo}_{7} \mathrm{O}_{24} \cdot 4 \mathrm{H}_{2} \mathrm{O}, \mathrm{C}_{6} \mathrm{H}_{8} \mathrm{O}_{6}, \mathrm{KH}_{2} \mathrm{PO}_{4}$, and distilled water.

\subsection{Sample Preparation}

Natural bentonite has collect from Batanghari, Indonesia (Fig. 1). Crusher and distilled water has used to prepare the natural bentonite then bentonite dried in $200^{\circ} \mathrm{C}$ for sixty minutes. Bentonite crushed using crusher and sieve on 100 mesh.



Figure 1. Administration map of Batanghari, Indonesia

\subsection{Activation of Bentonite}

50 gram bentonite was soaked in $200 \mathrm{ml}$ of $1.6 \mathrm{MHCl}$, bentonite stirred for a hour using $200 \mathrm{rpm}$ speed in magnetic stirrer. Bentonite filtered and washed with distilled water. The obtained residue was heated in $200^{\circ} \mathrm{C}$ for 60 minute. Activated bentonite is stored in a desiccator and ready for use for further processing

\subsection{Characterization and Analysis of P on Wastewater Palm Oil Factory}

The bentonite sample was characterized by XRD and SEM-EDS. The determination of Phosphate content refers to the workings of the Indonesian National Standard (SNI 06-6989.31-2005). Preparation of a standard phosphate solution was performed by dilution of the mother phosphate solution $100 \mathrm{ppm}$ to $0.2 \mathrm{ppm} ; 0.4 \mathrm{ppm} ; 0.8 \mathrm{ppm}$ and $1.0 \mathrm{ppm}$. Then measured with a UV-Vis spectrophotometer with a wavelength of $880 \mathrm{~nm}$

\section{Results and Discussion}

\subsection{Activation of Bentonite}

Bentonite activation is chemically treated using $\mathrm{HCl}$. This serves to convert the cations present in the pores of bentonite with $\mathrm{H}^{+}$ions and to cause the delamination of the release process of $\mathrm{Al}^{3+}, \mathrm{Fe}^{3+}, \mathrm{Mg}^{2+}$ from bentonite. This is due to increase $\mathrm{Si} / \mathrm{Al}$ ratio. Increasing $\mathrm{Si} / \mathrm{Al}$ ratio increases acid site of bentonite. This acid site serves as active side of bentonite. As acid site increases, it also increases the activity of bentonite. The addition of $\mathrm{HCl}$ can also cleanse the 
pores, remove the impurity compounds and rearrange the location of the ion being exchanged. Several study give some information about activator for bentonite such as $\mathrm{ZnCl}_{2}$ to reduce $\mathrm{Cd}$ (II) from wastewater using oven-dried $120^{\circ} \mathrm{C}$ for 24 hours (Kula, Ug, Ali, \& Karaog, 2008) this study will suggest alternative low cost adsorbent without dried for a long time. This research only need an hours of oven-dried in $200^{\circ} \mathrm{C}$ and successful made a activated bentonite. When the activation bentonite happened cation exchange of mineral salts $\left(\mathrm{Ca}^{2+}\right.$ and $\left.\mathrm{Mg}^{2+}\right)$ occurs in the bentonite interlayer layer with $\mathrm{H}^{+}$ions from the acid, followed by dissolution of $\mathrm{Al}^{3+}$ and other metal ions such as $\mathrm{Fe}^{3+}$ from lattice bentonite layer. The $\mathrm{Al}$ release process of bentonite is presented in the following equation:

$$
\begin{aligned}
& \left(\mathrm{Al}_{4}\right)\left(\mathrm{Si}_{8}\right) \mathrm{O} 20(\mathrm{OH}) 4+3 \mathrm{H}^{+} \longrightarrow\left(\mathrm{Al}_{3}\right)\left(\mathrm{Si}_{8}\right) \mathrm{O} 20(\mathrm{OH})_{2}+\mathrm{Al}^{3+}+2 \mathrm{H}_{2} \mathrm{O} \\
& \left(\mathrm{Al}_{4}\right)\left(\mathrm{Si}_{8}\right) \mathrm{O} 20(\mathrm{OH}) 4+6 \mathrm{H}^{+} \longrightarrow\left(\mathrm{Al}_{2}\right)\left(\mathrm{Si}_{8}\right) \mathrm{O} 20(\mathrm{OH}) 2+2 \mathrm{Al}^{3+}+4 \mathrm{H}_{2} \mathrm{O}
\end{aligned}
$$

\section{Characterization}

XRD used to find peak of natural bentonite and activated bentonite using $\mathrm{HCl}$. XRD pattern has compare using JCPDF card, phase kaolinite on natural bentonite has identified 14-0164 card, RIR 0.1.00, weight 29.016.7 and Mu/tho 0026.0 it's different with activated bentonite only on weight, activated bentonite more lighter 0.9 than natural bentonite. Activated bentonite have crystal structure higher than natural bentonite, it's an indicated that activated bentonite better as an adsorbent than natural bentonite (Fig. 2). The result of bentonite characteristic by XRD shows that bentonite of River Rengas Jambi consists of 3 types of minerals, namely kaolinite, quartz, and montmorillonite this minerals indicated bentonite have different mineral every single place, XRD analysis for bentonite minerals were found to be quartz, orthodase, albite, and illite (Bendou \& Amrani, 2014). The primary particles of montmorillonite have a sheet-like structure, as also shown in Fig. 3, with the major and minor axes ranging from $100 \mathrm{~nm}$ to $50 \mathrm{~nm}$. The sheet thickness is approximately $1 \mathrm{~nm}$. Secondary particles of montmorillonite are considered to be a lamination of 10-20 primary particles. Schematic microstructural model of montmorillonite (Fig. 3) (Kobayashi et al., 2017).



(a)



(b)

Figure 2. Diffractogram of natural bentonite (a) and activated bentonite $\mathrm{HCl}$ (b)



Figure 3. Montmorillonite microstructure

Bentonite from the Sungai Rengas area is a mixture of several minerals such as kaolinite, quartz, and montmorillonite. Montmorillonite is a mineral, containing $\mathrm{Al}_{2} \mathrm{O} 3.4 \mathrm{Si}_{2} \mathrm{H}_{2} \mathrm{O}$. Other minerals in bentonite are $\mathrm{Mg}$ and Ca. The bentonite lattice structure consists of a single plate located between $\mathrm{Al}_{2} \mathrm{O}_{3} \mathrm{SiO}_{2}$. Therefore, montmorillonite may expand, and have high water and adsorption cations.

Natural and activated bentonite from Sungai Rengas has characterization using SEM-EDS to find information about pores. Dry bentonite have pores size between 8 to $10 \mathrm{~nm}$ (Holmboe et al, 2012), bentonites are raw material that have 
good pores as an adsorbent like biochar( $\mathrm{S} \& \mathrm{P}, 2019)$. Natural bentonite have some minerals such as $\mathrm{C}, \mathrm{O}, \mathrm{Na}, \mathrm{Mg}, \mathrm{Al}$, $\mathrm{Si}, \mathrm{Cl}, \mathrm{K}, \mathrm{Ca}, \mathrm{Ti}, \mathrm{Mn}, \mathrm{Fe}, \mathrm{Cu}$ with different percentage and their component after pyrolysis bind to oxygen (Table 1). Activated bentonite have stronger peak than natural bentonite, usually activated bentonite have biggest pores than natural bentonite, but in this research did not happened significant different for pores sizes, this phenomena inform that bentonite is a good adsorbent although without activation. Recent study inform that bentonite can reduce aqueous phosphate (Pawar et al., 2016), absolutely bentonite can reduce phosphor too.

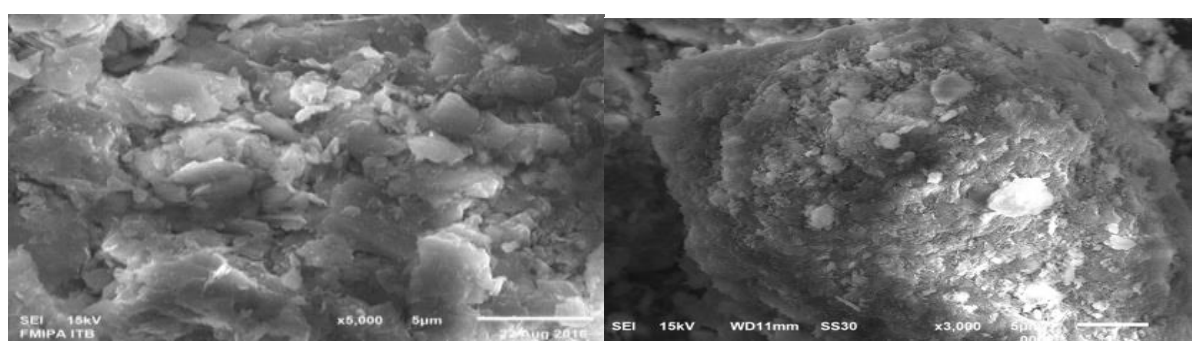

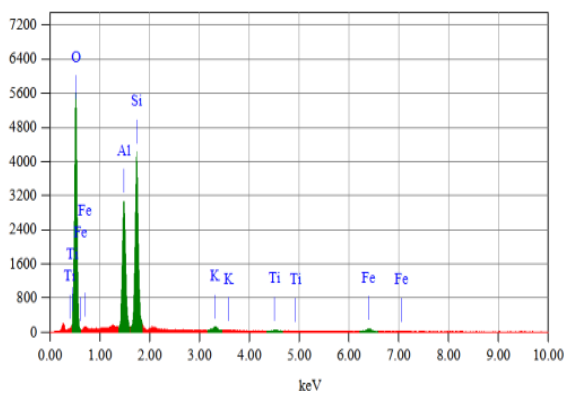

(a)



(b)

Figure 4. Characterization of Natural Bentonite SEM-EDS (a) and Activated Bentonite (b)

Table 1. Composition of Bentonite

\begin{tabular}{cccccc}
\hline \multirow{2}{*}{ Element } & \multicolumn{2}{c}{ Sample of Bentonit (\%) } & & \multicolumn{2}{c}{ Sample of Bentonite (\%) } \\
\cline { 2 - 3 } & $\begin{array}{c}\text { Natural } \\
\text { Bentonite }\end{array}$ & Activated Bentonite & Component & $\begin{array}{c}\text { Natural } \\
\text { Bentonite }\end{array}$ & Activated Bentonite \\
\hline $\mathrm{C}$ & - & 14.24 & $\mathrm{C}$ & - & 14,24 \\
$\mathrm{O}$ & 49.22 & 41.00 & $\mathrm{MgO}$ & - & 0,19 \\
$\mathrm{Na}$ & 0.01 & - & $\mathrm{Al}_{2} \mathrm{O}_{3}$ & 43.27 & 33,61 \\
$\mathrm{Mg}$ & - & 0.11 & $\mathrm{SiO}_{2}$ & 52.20 & 44,11 \\
$\mathrm{Al}$ & 22.90 & 17.79 & $\mathrm{Cl}$ & - & 0,75 \\
$\mathrm{Si}$ & 24.40 & 20,62 & $\mathrm{~K}_{2} \mathrm{O}$ & 0.10 & 0,04 \\
$\mathrm{Cl}$ & - & 0,75 & $\mathrm{CaO}$ & 0.04 & 0,01 \\
$\mathrm{~K}$ & 0,09 & 0,04 & $\mathrm{TiO}$ & 0,26 & 0,66 \\
$\mathrm{Ca}$ & 0.03 & 0.00 & $\mathrm{MnO}$ & - & 0,32 \\
$\mathrm{Ti}$ & 0,16 & 0,4 & $\mathrm{FeO}$ & 4.11 & 2,22 \\
$\mathrm{Mn}$ & - & 0,25 & $\mathrm{CuO}$ & - & 3,85 \\
$\mathrm{Fe}$ & 3.19 & 1,73 & & & \\
$\mathrm{Cu}$ & - & 3,08 & & & \\
\hline
\end{tabular}




\section{Determination of $\mathbf{P}$ content in Waste Water of Palm Oil Factory}

The standard calibration curve is made from a standard Phosphor solution with concentration of $0.2 \mathrm{mg} \mathrm{P} / \mathrm{L} ; 0.4 \mathrm{mg} \mathrm{P} / \mathrm{L}$; $0.8 \mathrm{mg} \mathrm{P} / \mathrm{L}$ and $1.0 \mathrm{mg} \mathrm{P} / \mathrm{L}$. Then measured its absorbance by UV-vis spectrophotometry at a wavelength of $880 \mathrm{~nm}$ (Table 2). Standard solution curve is made with the $x$-axis of concentration and the absorbance axis $y$, then $R 2=0.9975$ (Fig. 4) it has been in accordance with Lambert-Beer's law $\mathrm{A}=$ a.b.c, where the absorbance value (A) is directly proportional to the concentration value (c) (Mosorov, 2017).

Table 2. Standard of Phosphor

\begin{tabular}{cc}
\hline Concentration (ppm) & Absorbance \\
\hline 0.20 & 0.085 \\
0.40 & 0.180 \\
0.60 & 0.256 \\
0.80 & 0.327 \\
1.00 & 0.417 \\
\hline
\end{tabular}

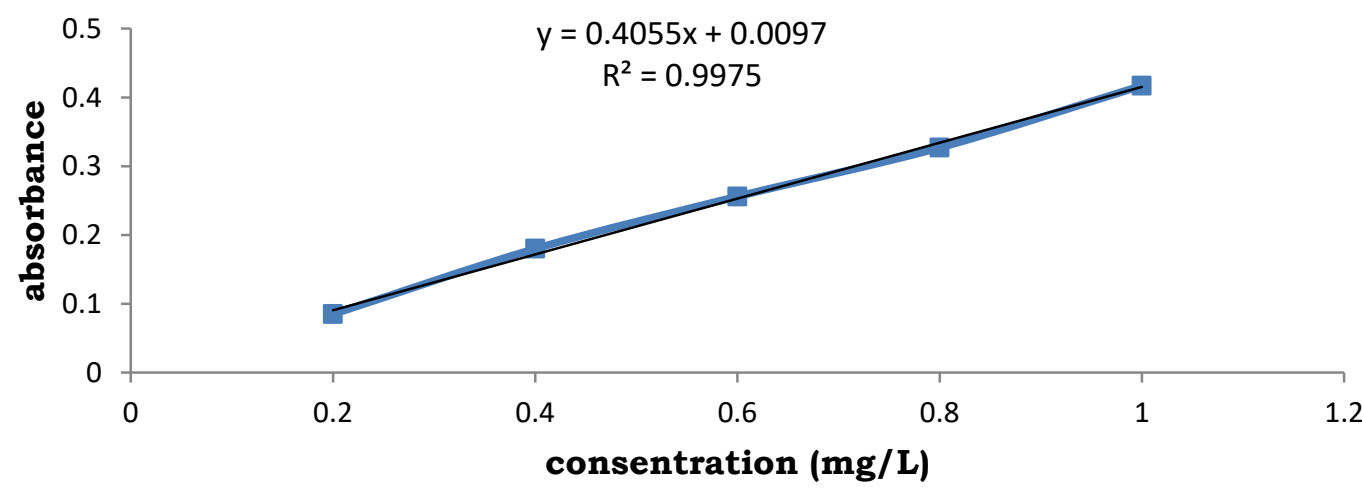

Figure 5. Calibration Curve

Table 3. Results of Phosphorous Analysis of Palm Oil Mill Effluent

\begin{tabular}{lcccc}
\hline \multicolumn{1}{c}{ Samples } & Absorbance & $\begin{array}{c}\text { Cons } \\
(\mathbf{m g} / \mathbf{L})\end{array}$ & $\mathbf{F P}$ & $\begin{array}{c}\text { Result } \\
(\mathbf{m g} \mathbf{P} / \mathbf{L})\end{array}$ \\
\hline Waste water in anaerobic ponds & 0,218 & 0,51368 & 50,0 & 25,684 \\
Waste water in aerobic ponds & 0,165 & 0,38298 & 25,0 & 9,575 \\
Blanco & $-0,016$ & 0,063 & 1,0 & $-0,063$
\end{tabular}

Based on the results of the analysis it is known that palm oil mill wastewater contains high phosphorus organic matter (Table 3). The standard phosphate level in wastewater for the low category is $<0.01 \mathrm{mg} \mathrm{P} / \mathrm{L}$ which causes the growth of algae to be blocked. Conversely, if phosphate levels in water are high, plant growth and algae will increase so that it can reduce the amount of dissolved oxygen in the water. The high content of phosphorus in water will have a negative impact on the sustainability of aquatic ecosystem.

The difference in the amount of $\mathrm{P}$ content in waste water is caused by differences in waste treatment processes. Anaerobic pond functions to convert fat into methane gas. The anaerobic pond also functions to hold waste water from the processing of palm oil mills for 60 days, the fat in this pond is converted into organic acids such as acetic acid, propionic acid, further formic acid water by anaerobic bacteria that produces methane gas. Whereas aerobic pond is the last pond in the process of treating wastewater and is used to provide the opportunity for liquid from the settling pond to absorb more oxygen from the air. This pond can hold waste liquid for 15 days. In this pond the waste liquid is enriched with oxygen content with an aerator, this oxygen is needed for the oxidation process (aerobic process) carried out by aerobic bacteria. Several study informs that aerobic pond can reduce pH, BOD, COD, TSS, total nitrogen, oil and grease and nutrient solution (Vijayaraghavan et al., 2007) 



1. Feed tank
4. Diffused aeration
2. Feed pump
5. Activated bentonte
3. Inlet
6. Outlet

Figure 6. Aerobic and Anaerobic pond Design

\section{The Influence of Bentonite Mass on P Absorption on Wastewater of Palm Oil Mill}

This adsorbent mass variation is intended to see the effect of adding bentonite weight to adsorption and finding the weight of bentonite required to achieve an equilibrium condition. Activated bentonite is low cost adsorbent that have better of absorption ability than natural bentonite. It caused by activated bentonite have biggest pores size after added $\mathrm{HCl}$ as an activator. $\mathrm{HCl}$ was selected caused effective acid to activation of adsorbent (Zhao et al., 2015). Comparison of natural and activated bentonite for phosphor sorption informs that activated bentonite better than natural bentonite every single treatment. Best formula for phosphor sorption is 0.1 grbentonite with $14.79 \mathrm{mg} / \mathrm{L}$ sorption (Table 4). This research give an information that local raw material (bentonite) we do not need many bentonite to reduce phosphor in waster palm oil.

Table 4. Results of $\mathrm{P}$ analysis after adsorption with bentonite mass variation

\begin{tabular}{ccc}
\hline \multirow{2}{*}{ Bentonite (gr) } & \multicolumn{2}{c}{ Absorbance of phosphor (mg/L) } \\
\cline { 2 - 3 } & Natural Bentonite & Activated Bentonite \\
\hline 0.1 & 12.72 & 14.79 \\
0.5 & 10.78 & 13.419 \\
1 & 6.62 & 4.279 \\
\hline
\end{tabular}

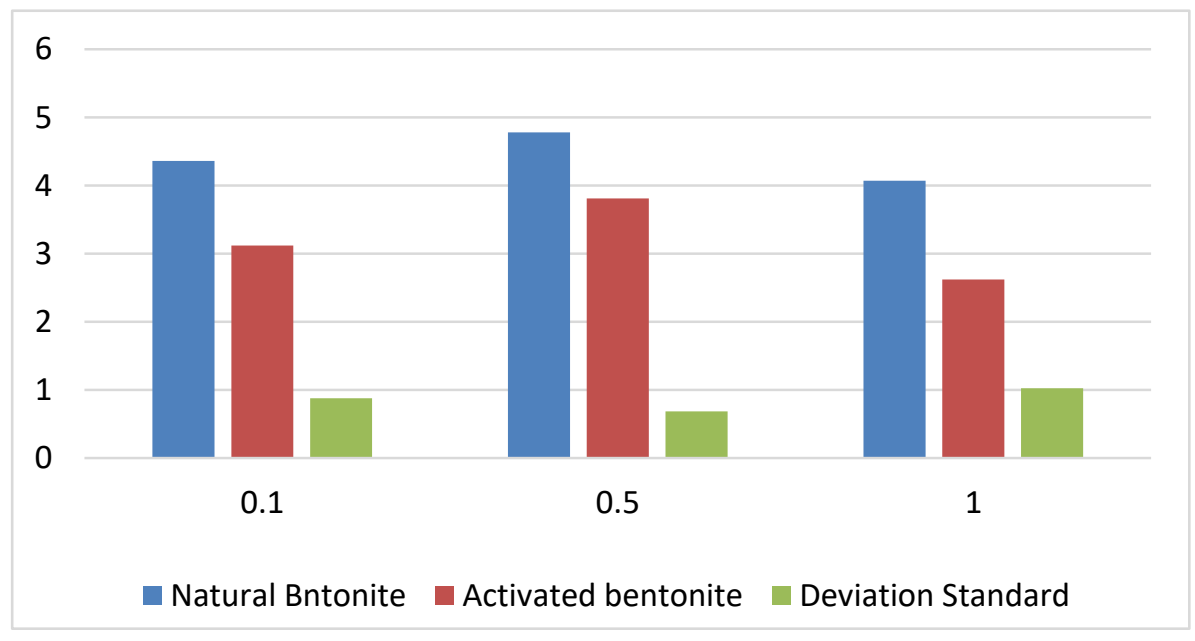

Figure 7. Phosphor Sorption by Bentonite 
According to Figure 5, a good absorption of $\mathrm{P}$ content occurs at a mass of 1 grams for natural bentonite with bentonite absorption of the resulting P content of $72.25 \%$, whereas for activated HClbentonite with bentonite absorption on the resulting $\mathrm{P}$ content is $83.38 \%$.Adsorption generally occurs on the whole surface but the magnitude is determined by the surface area of the adsorbent that is in direct contact with the adsorbate. The amount of adsorption is proportional to the specific surface area. The larger the surface area, the larger the adsorption occurs. This shows that the amount of adsorbent mass greatly influences the adsorption. Amount of bentonite used on adsorption affects many at least the amount of phosphor adsorbed. The adsorbate weight adsorbed is increasingly proportional to the increase in the amount of weight of bentonite used.

Deviation standard in this research are 0.057276 for 0.1 grbentonite, 0.072549 for 0.5 grbentonite and 0.078701 for 1 grbentonite. The interpretation of the standard deviation can be explained if the standard deviation value of a sample of data is equal to 0 (zero) so that all values in the data are the same. The greater the standard deviation value of a data, the greater the distance of each data point with the average value.

\section{Time Contact of Bentonite and Waste Palm Oil Mill}

Contact time is one of the decisive factors in the adsorption process because contact time is required to achieve equilibrium between the adsorbed solute and the remaining solution. The contact time is also the time used by the adsorbent and the adsorbate to interact directly. If the liquid phase containing the adsorbent is stationary, the adsorbate diffusion through the adsorbent surface will be slow. The contact time needed to reach adsorption equilibrium is another important parameter for adsorbents ( $\mathrm{Li}$ et al., 2011). Therefore, shaking is required to accelerate the adsorption process.

Absorption of $\mathrm{P}$ content occurs at a 90 minute contact time with the absorption of natural bentonite and activated bentonite to the resulting $\mathrm{P}$ content by $84.15 \%$ and $89.82 \%$ respectively. In both natural and activated bentonite, at minute 30 the amount of $\mathrm{P}$ adsorbed slightly due to the interaction time between $\mathrm{P}$ ions with the active site on the adsorbent relatively But in the 60th minute the amount of $\mathrm{P}$ absorbed actually decreased, this is because in this condition $\mathrm{P}$ ion has not entered all the pores into bentonite because it is possible there are still obstructed to enter. Thus, it is possible that P-ions already bonded to the active site of bentonite exist apart from the pores of bentonite during the adsorption process because the bonds that occur in the $\mathrm{P}$ ions with the active site on bentonite are the bonds of Van der Walls (Rodrigues et al., 2019). While in the 90th minute, the number of P-ions adsorbed at most compared to the other time. The adsorption efficiency showed that the adsorption equilibrium $\mathrm{P}$ using natural bentonite prior to activation and activated $\mathrm{HCl}$-bentonite was achieved in the 90th minute because in general $\mathrm{P}$ ion adsorption was slow before the 90th minute. From the above test results, the maximum mass of natural bentonite adsorbent and activated bentonite is 1 gram and maximum contact time for natural bentonite and activated bentonite is at 90 minutes. Bentonite is capable of lowering P levels in palm oil mill waste.

Activated Bentonite using $\mathrm{HCl}$ has a higher adsorption absorption capacity than natural bentonite. The use of $\mathrm{HCl}$ as an activator affects absorption because the mineral acid can dissolve the $\mathrm{SiO}_{2}$ and $\mathrm{Al}_{2} \mathrm{O}_{3}$ components that fill the pores of the adsorbent. This results in the opening of closed pores so as to increase the surface area of the adsorbent (Kobayashi et al, 2017) Activation of bentonite using acids also produced bentonite with larger active sites and greater surface similarities, resulting in bentonite with higher adsorption capacity than before activation. At the decrease of P content using natural bentonite and activated bentonite, the adsorption efficiency was obtained at $84 \%$ and $90 \%$, respectively. This suggests that the phosphate ion adsorption process using bentonite can be carried out, although the surface of the negligible arc is negatively charged. The surface of this negatively charged bentonite will inevitably inhibit the adsorption of phosphate ions because it will reject the refuse. The presence of iron oxide $\left(\mathrm{Fe}_{2} \mathrm{O}_{3}\right)$, alumina oxide $\left(\mathrm{Al}_{2} \mathrm{O}_{3}\right)$ and $\mathrm{SiO} 2$ which is an active site in bentonite framework can help the phosphate ion adsorption process. $\mathrm{Fe}$ and $\mathrm{Al}$ ions on the surface of bentonite will react with water molecules in the phosphate solution. Hydrated charge will form a positive charge by capturing $\mathrm{H}^{+}$ions or releasing $\mathrm{OH}^{-}$ions, after the hydration event occurs, on the surface of bentonite becomes positively charged by the presence of $\mathrm{H}^{+}$and $\mathrm{Al}^{3+}$. The formation of a positive charge on bentonite is caused by the inclusion of $\mathrm{H}+$ ions in the octahedral layer into $\mathrm{Al}(\mathrm{OH})_{3}$ and the tetrahedral layer into $\mathrm{SiOH}$ forming a hydrogen bond so as to bind the negatively charged phosphate. 
Table 5. Result of $\mathrm{P}$ analysis with variation of contact time

\begin{tabular}{cccc}
\hline & \multicolumn{2}{c}{ Absorbance Phosphor (mg/L) } \\
\cline { 2 - 4 } Contact time (minutes) & $\begin{array}{c}\text { Natural } \\
\text { Bentonite }\end{array}$ & Activated Bentonite & Deviation Standard \\
\hline 30 & 4.36 & 3.12 & 0.876812 \\
60 & 4.78 & 3.81 & 0.685894 \\
90 & 4.07 & 2.62 & 1.025305
\end{tabular}

Waste palm oil have similarity with wastewater in other industrial activities with parameters COD, BOD, TSS, organic matter and else (Darajeh et al., 2016). Recent study inform that waste palm oil can reduce use Co-processing of oil palm waste and waste oil via microwave co-torrefaction (Liew et al., 2019). Besides bentonite, biochar is a potential material to reduce heavy metals in waste palm oil, recent study inform biochar can reduce $\mathrm{Cu}$ and $\mathrm{Cd}$ from waste palm oil after pyrolysis between $400-600^{\circ} \mathrm{C}(\mathbf{F i g}$. 8) another research give an information about comparison of raw materials as a natural sorbents chitosan, bentonite and activated carbon to reduce residual oil and suspended solid (Ahmad et al., 2005). High acid content such as $\mathrm{HNO}_{3}$ and $\mathrm{H}_{2} \mathrm{SO}_{4}$ as an activator of bentonite can reduce free fatty acid in waste oil palm (Jeenpadiphat \& Tungasmita, 2014), thus, this activated bentonite in this research is powerful to reduce another parameters of waste material and helpful to reduce environmental damage by industrial activities.



Figure 8 . The influence of pyrolysis temperature on the percentage removal and adsorption capacity of $\mathrm{Cd}$ and $\mathrm{Cu}$ by raw material (biochar) pyrolyzed at different temperatures

\section{Conclusion}

Bentonites are potential raw material for reduce phosphor in waste palm oil. Natural bentonite and activated bentonite are low cost adsorbent to reduce phosphor, 0.1 grbentonite can reduce $12.72 \mathrm{mg} / 1$ phosphor and activated bentonite can reduce $14.79 \mathrm{mg} / 1,0.5 \mathrm{gr}$ natural bentonite can reduce $10.78 \mathrm{mg} / \mathrm{l}$ phosphor and activated bentonite can reduce $13.419 \mathrm{mg} / \mathrm{l}$ phosphor, $1 \mathrm{gr}$ natural bentonite can reduce 6.62 phosphor and activated bentonite can reduce $4.279 \mathrm{mg} / \mathrm{l}$ it caused by bentonite has reached the highest absorption point so that the absorption ability of bentonite drops. Optimum time contact for natural bentonite and activated is 60 minute. This research will helpful to solve environmental problem especially for waste palm oil in industry because this research use abundant material it will applicable for everyone.

\section{Reference}

Ahmad, A. L., Sumathi, S., \& Hameed, B. H. (2005). Residual oil and suspended solid removal using natural adsorbents chitosan, bentonite and activated carbon : A comparative study. Chemical Engineering Journal, 108, $179-185$. https://doi.org/10.1016/j.cej.2005.01.016

Bendou, S., \& Amrani, M. (2014). Effect of Hydrochloric Acid on the Structural of Sodic-Bentonite Clay. Journal of Minerals and Materials Characterization and Engineering, 2(5), 404-413. https://doi.org/10.4236/jmmce.2014.25045 
Chavalparit, O., Rulkens, W. H., \& Khaodhair, S. (2006). Options for Environmental Sustainability of The Crude Palm Oil Industry in Thailand Through Enhancement of Industrial Ecosystems. Environment, Development and Sustainability, 8(2), 271-272. https://doi.org/10.1007/s10668-005-9018-z

Darajeh, N., Idris, A., Reza, H., Masoumi, F., Nourani, A., Truong, P., \& Asrina, N. (2016). Modeling BOD and COD removal from Palm Oil Mill Secondary Ef fl uent in fl oating wetland by Chrysopogon zizanioides (L.) using response surface methodology. Journal of Environmental Management, 181, 343-352. https://doi.org/10.1016/j.jenvman.2016.06.060

Holmboe, M., Wold, S., \& Jonsson, M. (2012). Porosity investigation of compacted bentonite using XRD pro fi le modeling. Journal of Contaminant Hydrology, 128(1-4), 19-32. https://doi.org/10.1016/j.jconhyd.2011.10.005

Jeenpadiphat, S., \& Tungasmita, D. N. (2014). Applied Clay Science Esteri fi cation of oleic acid and high acid content palm oil over an acid-activated bentonite catalyst. Applied Clay Science, 87, 272-277. https://doi.org/10.1016/j.clay.2013.11.025

Kobayashi, I., Owada, H., Ishii, T., \& Iizuka, A. (2017). Evaluation of specific surface area of bentonite-engineered barriers for Kozeny-Carman law. Soils and Foundations, 57(5), 683-697. https://doi.org/10.1016/j.sandf.2017.08.001

Kula, I., Ug, M., Ali, C., \& Karaog, H. (2008). Adsorption of Cd ( II ) ions from aqueous solutions using activated carbon prepared from olive stone by $\mathrm{ZnCl} 2$ activation. Bioresource Technology, 99, 492-501. https://doi.org/10.1016/j.biortech.2007.01.015

Li, N., Zhang, L., Chen, Y., Tian, Y., \& Wang, H. (2011). Adsorption behavior of Cu ( II ) onto titanate nanofibers prepared by alkali treatment. Journal of Hazardous Materials, 189(1-2), 265-272. https://doi.org/10.1016/j.jhazmat.2011.02.031

Liew, R. K., Osman, M. S., \& Peng, W. (2019). Co-processing of oil palm waste and waste oil via microwave co-torrefaction: A waste reduction approach for producing solid fuel product with improved properties. Process Safety and Environmental Protection, 128, 30-35. https://doi.org/10.1016/j.psep.2019.05.034

Mosorov, V. (2017). The Lambert-Beer law in time domain form and its application. Applied Radiation and Isotopes, 128, 1-5. https://doi.org/10.1016/j.apradiso.2017.06.039

Naswir, M. (2016). Study the Effectiveness of Waste Management in Wwtp Palm Oil Factory in Order Anticipation of Environmental Pollution ( Case Study Wwtp Palm Oil Factory DMP Company ). 10(2), 60-67. https://doi.org/10.9790/2402-10226067

Naswir, M., Arita, S., Marsi, \& Salni. (2013). Characterization of Bentonite by XRD and SEM-EDS and Use to Increase $\mathrm{PH}$ and Color Removal, Fe and Organic Substances in Peat Water. Journal of Clean Energy Technologies, 1(4), 313-317. https://doi.org/10.7763/jocet.2013.v1.71

Naswir, M., Arita, S., Marsi, \& Sani. (2014). Activation of Bentonite and Application for Reduction pH, Color, Organic Substance, and Iron (Fe) in the Peat Water. Science Journal of Chemistry, 1(5), 74. https://doi.org/10.11648/j.sjc.20130105.14

Naswir, M., Arita, S., \& Sani. (2011). Treatment of Peat Water Using Local Raw Material Formulations of Jambi, Indonesia. Asian Journal of Chemistry, 5(1), 43-46. https://doi.org/10.3153/jfscom.2011005

Naswir, M., \& Lestari, I. (2014). Characterization Active Carbon and Clum Shell In Reducing pH , Color , COD , Fe and Organic Matter On Peat Water. International Journal of Innovative Research in Advanced Engineering (IJIRAE), 1(11), 137-146.

Pawar, R. R., Gupta, P., Bajaj, H. C., \& Lee, S. (2016). Science of the Total Environment Al-intercalated acid activated bentonite beads for the removal of aqueous phosphate. Science of the Total Environment. https://doi.org/10.1016/j.scitotenv.2016.08.040

Rodrigues, F. K., Salau, N. P. G., \& Dotto, G. L. (2019). Separation and Puri fi cation Technology New insights about reactive red 141 adsorption onto multi - walled carbon nanotubes using statistical physics coupled with Van der Waals equation. Separation and Purification Technology, 224(March), 290-294. https://doi.org/10.1016/j.seppur.2019.05.042

S, R., \& P, B. (2019). The potential of lignocellulosic biomass precursors for biochar production: Performance, mechanism and wastewater application-A review. Industrial Crops and Products, 128(May 2018), 405-423. https://doi.org/10.1016/j.indcrop.2018.11.041

Taiz, L., \& Zeiger, E. (2002). Plant Physiology (3rd ed.). Sinauer Associates. 
Vijayaraghavan, K. Ã., Ahmad, D., Ezani, M., \& Abdul, B. (2007). Aerobic treatment of palm oil mill effluent. Journal of Environmental Management, 82(1), 24-31. https://doi.org/10.1016/j.jenvman.2005.11.016

Wibowo, Y., \& Sadikin, A. (2019). Biology in the 21st-Century: Transformation in biology science and education in supporting the sustainable development goals. Jurnal Pendidikan Biologi Indonesia, 5(2). doi:https://doi.org/10.22219/jpbi.v5i2.7956

Wibowo, Y. G., Ramadan, B. S., Anurogo, D., \& Illiandri, O. (2019). Qualitative Analysis To Reduce Unhealthy Houses on Kerinci District , 1-40. https://doi.org/10.20944/preprints201904.0196.v1

Winarno, H., Muhammad, D., Ashyar, R., \& Wibowo, Y. G. (2019). Pemanfaatan Limbah Fly Ash dan Bottom Ash dari PLT SUMSEL-5 Sebagai Bahan Utama Pembuatan Paving Block. Jurnal Teknika, 11(1), 1067-1070.

Yuliyanti, A., Warmada, I. W., \& Titisari, A. D. (2011). Characteristics and Genesis of Montmorilonitic Claystone from Bandung Area, Wonosegoro, Boyolali, Central Java , Indonesia. Journal of Applied Geology, 3(1), 64-71.

Zhao, Y., Qi, W., Chen, G., Ji, M., \& Zhang, Z. (2015). Behavior of Cr ( VI ) removal from wastewater by adsorption onto $\mathrm{HCl}$ activated Akadama clay. Journal of the Taiwan Institute of Chemical Engineers, 000, 1-8.

https://doi.org/10.1016/j.jtice.2014.12.016

\section{Copyrights}

Copyright for this article is retained by the author(s), with first publication rights granted to the journal.

This is an open-access article distributed under the terms and conditions of the Creative Commons Attribution license (http://creativecommons.org/licenses/by/4.0/). 